\title{
Agro-Morphological Evaluation of Improved Bread Wheat (Triticum aestivum L) Varieties for Highland Areas of Western Guji, Southern Oromia
} Natol Bakala $^{1 *}$, Ibsa Jibat ${ }^{2}$, Belda Idao ${ }^{2}$

${ }^{1}$ Oromia Agricultural Research Institute, Bako Agricultural Research Center, Ethiopia

${ }^{2}$ Oromia Agricultural Research Institute, Yabello Pastoral and Dryland Agricultural Research Center, Ethiopia

DOI: $10.36347 /$ sajb.2022.v10i01.002

| Received: 02.12.2021 | Accepted: 04.01.2022 | Published: 30.01.2022

*Corresponding author: Natol Bakala

Oromia Agricultural Research Institute, Bako Agricultural Research Center, Ethiopia

Abstract

Original Research Article

Bread wheat (Triticum aestivum L.) is the most important cereal occupying a protruding position among major food crops in the world in terms of acreage and production and is an important cereal crop which is receives the most attention of specialists in plant breeding and production in the world wide in general and in Ethiopia in particular. This experiment was conducted on five bread wheat varieties Mandoyo, Mada-Walabu, Sofumar, Dure and Sanate against local check at Bule hora woreda to identify and recommend high yielder, insect pest tolerant, and stable varieties. The experiment was carried out in a Randomized Complete Block Design (RCBD), with three replications. Yield and yield related parameters were analyzed using SAS statistical software version 9.0. Most of yields and yield related components were significantly different between the varieties at $5 \%$ probability level. Based on the mean separation, the highest average grain yield was recorded from Sanate variety $3926.3 \mathrm{~kg} / \mathrm{ha}$ while, the lowest average yield $(2753.2 \mathrm{~kg} / \mathrm{ha}) \mathrm{was}$ recorded from Local check. From total analysis Sanate variety had a yield advantage over the check (Local). Therefore, we suggest that, farmers, state farms and other private bread wheat producers located at the study areas and with similar agro ecologies are recommended to use Sanate variety to increase bread wheat yield.

Keywords: Bread wheat; Evaluation; Highland; Grain yield.

Copyright $(92022$ The Author(s): This is an open-access article distributed under the terms of the Creative Commons Attribution 4.0 International License (CC BY-NC 4.0) which permits unrestricted use, distribution, and reproduction in any medium for non-commercial use provided the original author and source are credited.

\section{INTRODUCTION}

Bread wheat (Triticum aestivum L.) is the world's leading cereal grain and more than one-third of the population of the world uses as a staple food and contributes more calories and proteins to the world diet than any other cereal crops. In Sub-Saharan African countries, the consumption of wheat increased from time to time (Mason et al., 2012; Negassa et al., 2013; Chimdesa, 2014). Ethiopia is the second wheat producer in sub-Saharan after South Africa (FAO, 2019). Wheat is the fourth largest cereal crop grown in Ethiopia and about 56 million smallholder farmers engaged on wheat production, which makes about 40 percent of all small farmers in the country (Gebreselassie et al., 2017; Rashid, et al., 2019). Bread wheat is a staple food in the diets of several Ethiopian, providing about 15 percent of the caloric intake for the countries over 90 million population (FAO, 2019; Minot et al., 2019).

Wheat is grown at an altitude ranging from 1500 to 3000 m.a.s.l, between 6-160 $\mathrm{N}$ latitude and
35-420 E longitude in Ethiopia. The most suitable agroecological zones, however, fall between 1900 and 2700_m.a.s.1. (Abu, 2012; Shibeshi, 2019). In Ethiopia, bread wheat improvement has started in 1949 and up to now many varieties have been released by the national and regional research institutes (Tarekegne et al., 1995). However, those varieties are not widely distributed to all parts of the country. This is because of several constraints including the remoteness and in accessibilities of the growing areas that limited to test the adaptability and yields of the varieties in such areas. It is necessary to evaluate varieties for the intended growing regions since varieties were recommended as high yielding after evaluating a few representative wheat growing areas, in other words the varieties were not evaluated in all wheat growing regions.

Nevertheless, the productivity of wheat has remained very low mainly because improved production technologies have not been adopted by the farming community. To change the status quo, therefore, it was 
Natol Bakala et al., Sch Acad J Biosci, Jan, 2022; 10(1): 5-10

felt necessary to conduct a multidisciplinary review of wheat research in Ethiopia (Zerga et al., 2017). At western Guji zone of Oromia region are one of the areas where improved varieties are not widely distributed so far, most probably due to the above indicated problems. Particularly, the potential of the area to wheat crop is not exploited due to lack of improved varieties. There is no detail information indicating the adaptability and production status of the improved bread wheat varieties in the area. Therefore, the objective of the study was to evaluate, select and recommend high yielder, tolerant to diseases, more adapted and stable bread wheat variety/ies in the study area.

\section{MATERIALS AND METHODS \\ 2.1 Description of the Study Area}

Field experiment was conducted at western Guji of Bule hora woreda, for three consecutive years (2017 to 2019). The study sites were recognized with an elevation of 2000 masl having bimodal rainfall distribution pattern. Workable soil type and. Major field crops grown around the study areas are Maize, wheat, barely and

\subsection{Experimental Materials and design}

Five released varieties (Sanate, Mandoyo, Madawalabu, sofumer and Dure) collected form Sinana Agricultural Research Center were evaluated against to local check. Randomized Complete Block Design (RCBD) with three replications, having a plot size of $1.2 \mathrm{mx} 2 \mathrm{~m}$ was used at the spacing of $1.5 \mathrm{~m}, 0.75 \mathrm{~m}$ and $0.2 \mathrm{~m}$ between replications, plot and row, respectively. Seed was sown at the rate of $125 \mathrm{~kg} / \mathrm{ha}$ with drilling method. Inorganic fertilizer was applied at the rate of $100 \mathrm{~kg} / \mathrm{ha}$ of Urea and $100 \mathrm{~kg} / \mathrm{ha}$ NPS. All recommended agronomic practices were done uniformly.

\subsection{Collected data \\ Plot base data}

Data Collection The data on the following attributes was collected on the basis of the central four rows in each plot.

i. Days to $50 \%$ heading (DTH): The number of days from date of sowing to the stage where $75 \%$ of the spikes have fully emerged.

ii. Days to $90 \%$ maturity (DTM): The number of days from sowing to the stage when $90 \%$ of the plants in a plot have reached physiological maturity.

iii. Grain yield (GY): Grain yield in grams obtained from the central four rows of each plot and converted to kilograms per hectare at $12.5 \%$ moisture content. (5)

iv. Thousand kernel weights (TKW): Weight of 1000 seeds in gram.

v. Above ground biomass (BM): The plants within the four central rows were harvested and weighed in grams.

\section{Plant base data}

Ten plants were randomly selected from the four central rows for recording the following observations:

- Number of productive Tillers (TN): The average number of productive tillers with heading

- Plant height $(\mathrm{PH})$ : The average height in $\mathrm{cm}$ from ground level to the tip of the spike.

- $\quad$ Spikelet per spike (SPS): The average number of spikelets per spike (5).

- Spike length (SL): The average spike length in $\mathrm{cm}$ from its base to the tip.

\section{Data Analysis}

Before computing the combined analysis, error variance homogeneity test was performed using the procedure suggested by Gomez and Gomez (1984). The collected data were organized and analyzed using SAS statistical package (SAS, 2006 version 9.03). Mean separation was done by using least significant difference (LSD) at $1 \%$ probability level through employing the procedure developed by Gomez and Gomez (1984). In the combined analysis of variance, over year were considered random and genotypes were considered fixed.

The mathematical model used for analysis of variance was:

$Y i j k=\mu+G i+Y j+G Y i j+B k(j)+E i j k$

Where:

$Y i j k=$ observed value of genotype $\mathrm{i}$ in block $\mathrm{k}$ of year $\mathrm{j}$ $\mu=$ grand mean $=$

$\mathrm{Gi}=$ effect of genotype $\mathrm{i}$

$\mathrm{Yi}=$ effect of year $\mathrm{j}$

GYij=the interaction effect of genotype $i$, year $j$

$\mathrm{Bk}(\mathrm{j})=$ effect of block $\mathrm{k}$ in location/environment

Eijk = random error or residual effect of genotypei in block $\mathrm{k}$ of location $\mathrm{j}$

\section{RESULT AND DISCUSSION \\ 3.1 Analysis of Variances (ANOVA)}

The analyses of variances revealed highly significant $(\mathrm{P} \leq 0.01)$ differences among genotypes, environments and their interactions for grain yield (Table 1). In the same way, the significant difference of genotype, growing season and their interaction on grain yield has been reported by (Abay and Bjornstad (2009); Gebru and Abay, 2013; Chimdesa et al., 2017; Tulu and Wondimu., 2019)

The combined ANOVA indicated presence of significant differences at $(\mathrm{P} \leq 0.05)$ among the evaluated bread wheat varieties for all the characters except for total biomass. This indicates presence of genetic variability among the evaluated bread wheat varieties. Similarly, Kebede et al., (2019), Gedifew et al., (2020) obtained a significant variation for plant height and spike length and a non-significant grain yield difference among the studied varieties. 
The combined ANOVA of the bread wheat varieties indicated a highly significant difference among the tested bread wheat varieties $(\mathrm{P} \leq 0.05)$ for tiller number and seed per spike (SPS), while non-significant variation was observed among bread wheat varieties in biomass.

Highly significant difference was observed for all traits, across all years. This is may be due to the fluctuation of environment from year to year. The rank of genotypes was not significantly changed, Sanate variety was the winner across all Environments.
In other cases, highly significant effect of environment by genotypes interaction was exhibited on days to flowering, days of maturity, number of productive tillers, thousand kernel weight and grain yield. In addition, non- significant effect of environment by genotype interaction was depicted on plant height, spike length, spikelet per spike, biomass. The result obtained was in accordance with Mehari et al., (2015); Mwadzingeni et al., (2016) who reported significant differences among genotypes for most of the traits including day to heading, days to maturity, plant height, thousand kernel weight across environments.

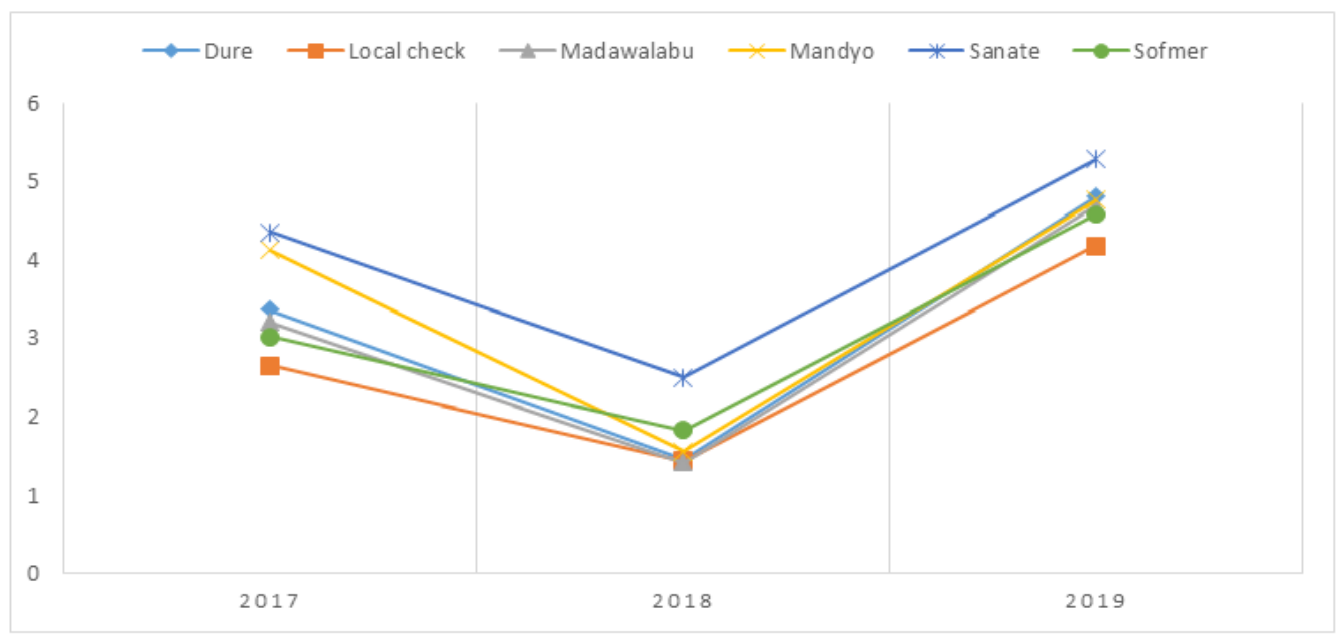

Figure 1: Mean grain yield of all genotypes across three years

Based on the performance of genotypes across cropping season, the 2019 cropping season outperformed all others, with a high yield from the variety Sanate (5.27 tone/ha), while the 2018 cropping season was less productive (1.42 tone/ha) grain output from the Madawalabu (Figure 1). In all cropping seasons, the Sanate variety produced higher yields, whereas the local check produced lower yields than all other varieties. As a result, we may infer that the cropping season of 2019 was better than all others, whereas the cropping season of 2018 was the worst cropping season for bread wheat production in study area (Figure 1).

\subsection{Mean performance of genotypes across years}

The mean performance of genotypes was significantly different from each other.

\section{Days to $50 \%$ heading and Days to $90 \%$ physiological maturity}

Days to flowering and days to maturity was ranged from 59.60 to 70.00 and 108.56 to 122.33 days respectively. Dure variety (108.56 days) was the earliest while local check was takes longer time to mature. In other cases, Dure and Sanate variety was early maturing varieties (108.56) and (116.22) days respectively. In the same line, significant days to heading and days to maturity was reported by different authors Asaye et al., (2013); Ferede, (2016); Baye et al., (2018).

\section{Plant height}

Inters of plant height, the significance difference was observed among genotypes. Sofumer $(87.82 \mathrm{~cm})$ was the longest plant height followed by Sanate $(86.78 \mathrm{~cm})$ while Mandoy $(73.09 \mathrm{~cm})$ was the shortest one. Significant variation among bread wheat genotypes for plant height was also reported by many authors including Demelash et al., (2013), Chimdesa et al., (2017), Baye et al., (2018). In contrast, nonsignificant variation among bread wheat varieties was reported by Dargo and Shiferaw, (2017).

\section{Spike length}

Significant difference was observed among genotypes in spike length. The heist spike length was recorded for Sanate $(12.00 \mathrm{~cm})$, followed by Madawalabu $(11.32 \mathrm{~cm})$ while the lowest spike length was recorded for Local check $(8.11 \mathrm{~cm})$.

\section{Number of productive tillers}

The highest tiller number was recorded for Madawalabu (3.44) variety while the lowest was recorded for Dure (2.78). Zerga et al., (2017) and Wardofa et al., (2019) were reported significant difference of different genotypes in number of tillers. 
Natol Bakala et al., Sch Acad J Biosci, Jan, 2022; 10(1): 5-10

Table 1: Mean performance of yield and yield related traits of Bread wheat varieties during 2017, 2018 and 2019 main cropping season at Bule hora Woreda of western Guji Zone

\begin{tabular}{|c|c|c|c|c|c|c|c|c|c|}
\hline Genotypes & DF & DM & PH $(\mathrm{cm})$ & $\mathrm{SL}(\mathrm{cm})$ & $\mathbf{T N}$ & SPS & BM (ton/ha) & TKW & GY (ton/ha) \\
\hline \multicolumn{10}{|c|}{2017 cropping season } \\
\hline Dure & $52.00 \mathrm{~b}$ & $98.33 \mathrm{c}$ & $78.87 \mathrm{~b}$ & $8.97 b c$ & $2 \mathrm{c}$ & $29.00 \mathrm{a}$ & $6.86 \mathrm{ab}$ & $29.17 \mathrm{ab}$ & $3.36 \mathrm{~b}$ \\
\hline Local check & $68.67 \mathrm{a}$ & $115.00 \mathrm{a}$ & $77.33 \mathrm{~b}$ & $7.67 \mathrm{c}$ & $3.33 \mathrm{ab}$ & $26.33 \mathrm{a}$ & $5.91 b$ & $28.00 \mathrm{~b}$ & $2.65 \mathrm{~d}$ \\
\hline Madawalabu & $63.67 \mathrm{~b}$ & $105.67 \mathrm{~b}$ & $79.80 \mathrm{~b}$ & $11.57 \mathrm{a}$ & $3.67 \mathrm{a}$ & $19.73 a$ & $7.97 \mathrm{ab}$ & $29.00 \mathrm{ab}$ & $3.18 \mathrm{bc}$ \\
\hline Mandyo & $61.33 b$ & $104.33 b$ & $74.07 \mathrm{~b}$ & $8.97 \mathrm{bc}$ & $3.07 \mathrm{ab}$ & $21.00 \mathrm{a}$ & $9.18 \mathrm{a}$ & $28.50 \mathrm{~b}$ & $4.12 \mathrm{a}$ \\
\hline Sanate & $65.00 \mathrm{~b}$ & $107.00 \mathrm{~b}$ & $85.53 \mathrm{ab}$ & $11.33 \mathrm{a}$ & $3.27 \mathrm{ab}$ & $30.33 a$ & 7.29ab & $30.83 a$ & $4.34 \mathrm{a}$ \\
\hline Sofmer & $65.33 \mathrm{~b}$ & $105.00 \mathrm{~b}$ & $91.93 \mathrm{a}$ & $10.30 \mathrm{ab}$ & $2.67 \mathrm{bc}$ & $34.67 \mathrm{a}$ & $7.00 \mathrm{ab}$ & $30.67 \mathrm{a}$ & $3.01 \mathrm{c}$ \\
\hline $\mathrm{CV}$ & 1.91 & 1.90 & 81.26 & 11.45 & 17.26 & 60.53 & 21.30 & 3.90 & 5.15 \\
\hline LSD & 2.18 & 3.66 & 11.68 & 2.04 & 0.94 & 29.56 & 2.86 & 2.09 & 3.22 \\
\hline \multicolumn{10}{|c|}{2018 cropping season } \\
\hline Dure & $62.00 \mathrm{~d}$ & $110.33 d$ & $76.60 \mathrm{ab}$ & $8.03 \mathrm{~b}$ & $2.33 \mathrm{ab}$ & $50.00 \mathrm{ab}$ & $2.77 \mathrm{c}$ & $29.38 b$ & $1.46 \mathrm{c}$ \\
\hline Local check & $71.00 \mathrm{a}$ & $126.67 \mathrm{a}$ & $77.73 \mathrm{ab}$ & $7.00 \mathrm{c}$ & $2.33 \mathrm{ab}$ & $43.00 \mathrm{~b}$ & $3.11 \mathrm{bc}$ & $38.09 \mathrm{a}$ & $1.44 \mathrm{c}$ \\
\hline Madawalabu & $68.33 b$ & $125.00 \mathrm{a}$ & $74.53 \mathrm{ab}$ & $10.17 \mathrm{a}$ & $2.33 \mathrm{ab}$ & $46.00 \mathrm{ab}$ & $2.83 \mathrm{c}$ & $36.24 a$ & $1.42 \mathrm{c}$ \\
\hline Mandoyo & $64.67 c$ & $121.00 \mathrm{~b}$ & $70.07 \mathrm{~b}$ & $8.10 \mathrm{~b}$ & $3.00 \mathrm{a}$ & $47.57 \mathrm{ab}$ & $3.95 \mathrm{ab}$ & $27.93 b$ & $1.55 \mathrm{c}$ \\
\hline Sanate & $65.33 c$ & $120.00 \mathrm{bc}$ & $85.27 \mathrm{a}$ & $10.33 \mathrm{a}$ & $2.00 \mathrm{~b}$ & $56.00 \mathrm{a}$ & $4.15 a$ & $35.27 \mathrm{a}$ & $2.50 \mathrm{a}$ \\
\hline Sofmer & $66.33 \mathrm{bc}$ & $117.33 \mathrm{c}$ & $79.53 \mathrm{ab}$ & $8.63 \mathrm{~b}$ & $2.67 \mathrm{ab}$ & $48.00 \mathrm{ab}$ & $3.18 \mathrm{abc}$ & $34.55 \mathrm{a}$ & $1.82 \mathrm{~b}$ \\
\hline $\mathrm{CV}$ & 1.82 & 1.66 & 8.53 & 4.10 & 19.28 & 12.25 & 16.61 & 5.93 & 7.41 \\
\hline LSD & 2.20 & 3.63 & 11.99 & 0.65 & 0.86 & 10.79 & 1.01 & 3.62 & 2.28 \\
\hline \multicolumn{10}{|c|}{2019 cropping season } \\
\hline Dure & $64.67 \mathrm{~d}$ & $117.00 \mathrm{~b}$ & $80.53 \mathrm{ab}$ & $11.17 \mathrm{~cd}$ & $4.00 \mathrm{ab}$ & $58.00 \mathrm{~b}$ & $7.82 \mathrm{a}$ & $36.10 \mathrm{c}$ & $4.81 b$ \\
\hline Local check & $70.33 \mathrm{a}$ & $125.33 \mathrm{a}$ & $85.00 \mathrm{ab}$ & $9.67 \mathrm{e}$ & $3.00 \mathrm{~b}$ & $35.00 \mathrm{c}$ & $7.04 \mathrm{a}$ & $41.33 b$ & $4.17 \mathrm{c}$ \\
\hline Madawalabu & $66.67 \mathrm{bc}$ & $119.33 b$ & $85.47 \mathrm{ab}$ & $12.23 \mathrm{bc}$ & $4.33 \mathrm{a}$ & $60.67 b$ & $8.18 \mathrm{a}$ & $48.30 \mathrm{a}$ & $4.69 \mathrm{~b}$ \\
\hline Mandoyo & $66.33 \mathrm{bc}$ & $118.67 \mathrm{~b}$ & $75.13 \mathrm{~b}$ & $10.10 \mathrm{de}$ & $4.67 \mathrm{a}$ & $60.33 b$ & $9.23 \mathrm{a}$ & $32.90 \mathrm{c}$ & $475 b$ \\
\hline Sanate & $67.33 \mathrm{~b}$ & $121.67 \mathrm{ab}$ & $89.53 a$ & $14.33 \mathrm{a}$ & $4.67 \mathrm{a}$ & $67.33 \mathrm{a}$ & $9.14 \mathrm{a}$ & $34.50 \mathrm{c}$ & $5.27 \mathrm{a}$ \\
\hline Sofmer & $65.67 \mathrm{~cd}$ & $120.33 b$ & $92.00 \mathrm{a}$ & $12.70 \mathrm{~b}$ & $4.33 \mathrm{a}$ & $56.00 \mathrm{~b}$ & $9.21 \mathrm{a}$ & $43.93 b$ & $4.57 \mathrm{~b}$ \\
\hline $\mathrm{CV}$ & 1.22 & 2.24 & 8.62 & 5.37 & 15.80 & 4.63 & 34.87 & 5.11 & 3.39 \\
\hline LSD & 1.49 & 4.90 & 13.26 & 1.14 & 1.20 & 4.74 & 5.35 & 3.68 & 2.90 \\
\hline
\end{tabular}

Table 2: Combined Mean Square of Bread wheat genotypes during 2017, 2018 and 2019 main cropping season at Bule hora Woreda of western Guji Zone

\begin{tabular}{|c|c|c|c|c|c|c|c|c|c|c|}
\hline $\begin{array}{l}\text { Source of } \\
\text { variation }\end{array}$ & df & FD & MD & PH & SL & $\mathbf{T N}$ & SPS & BM & TSW & GY \\
\hline $\begin{array}{l}\text { Environmen } \\
\mathrm{t}\end{array}$ & 2 & $92.13 * * *$ & $\begin{array}{l}1233.17 * * \\
*\end{array}$ & $241.83^{*}$ & $\begin{array}{l}41.19 * * \\
*\end{array}$ & $\begin{array}{l}13.91 * * \\
*\end{array}$ & $\begin{array}{l}4168.79 * * \\
*\end{array}$ & $\begin{array}{l}130.44 * * \\
*\end{array}$ & $\begin{array}{l}468.05 * * \\
*\end{array}$ & $\begin{array}{l}41.12 * * \\
*\end{array}$ \\
\hline Genotypes & 5 & $\begin{array}{l}104.25 * * \\
*\end{array}$ & $178.40 * * *$ & $\begin{array}{l}270.06 * * \\
*\end{array}$ & $\begin{array}{l}19.53 * * \\
*\end{array}$ & $0.88^{*}$ & $268.76^{*}$ & $4.96 \mathrm{~ns}$ & $85.78 * * *$ & $1.71 * * *$ \\
\hline $\begin{array}{l}\text { Environmen } \\
\mathrm{t} * \text { Genotype }\end{array}$ & 10 & $17.55 * * *$ & $17.97 * *$ & $21.71 \mathrm{~ns}$ & $0.85 \mathrm{~ns}$ & $0.84^{*}$ & $127.46 \mathrm{~ns}$ & $1.11 \mathrm{~ns}$ & $37.48 * * *$ & $0.25 * * *$ \\
\hline Error & & 1.19 & 5.10 & 45.93 & 0.59 & 0.31 & 102.01 & 3.81 & 3.12 & 0.02 \\
\hline
\end{tabular}

$\mathrm{FD}=$ days to heading, $\mathrm{DM}=$ days to physiological maturity, $\mathrm{PH}=$ plant height, $\mathrm{SL}=$ spike length, $\mathrm{TN}=$ number of productive tillers, SPS= number of spikelet's per spike, $\mathrm{BM}=$ biomass

Table 3: Combined Mean Performance of Bread Wheat Variety at Western Guji of Bule hora woreda during 2017, 2018 and 2019

\begin{tabular}{|c|c|c|c|c|c|c|c|c|c|}
\hline Genotypes & $\begin{array}{l}\text { FD (no } \\
\text { days) }\end{array}$ & $\begin{array}{l}\text { MD (no } \\
\text { days) }\end{array}$ & PH (cm) & SL (cm) & TN (no) & SPS (no) & $\begin{array}{l}\text { BM } \\
\text { (tone//ha) }\end{array}$ & TSW & GY (tone/ha) \\
\hline Local & $70.00 \mathrm{a}$ & $122.33 \mathrm{a}$ & $80.02 \mathrm{~b}$ & $8.11 \mathrm{~d}$ & $2.89 \mathrm{bc}$ & $34.78 b$ & $5.35 b$ & $35.81 \mathrm{~b}$ & $2.75 \mathrm{~d}$ \\
\hline Madawalabu & $66.22 b$ & $116.67 \mathrm{~b}$ & $79.93 b$ & $11.32 \mathrm{a}$ & $3.44 \mathrm{a}$ & $42.13 \mathrm{ab}$ & $6.33 \mathrm{ab}$ & $37.85 \mathrm{a}$ & $3.09 \mathrm{c}$ \\
\hline Sanate & $65.88 \mathrm{~b}$ & $116.22 \mathrm{~cd}$ & $86.78 \mathrm{a}$ & $12.00 \mathrm{a}$ & $3.31 \mathrm{ab}$ & $51.22 \mathrm{a}$ & $6.86 \mathrm{~b}$ & $33.53 c$ & $4.04 \mathrm{a}$ \\
\hline Sofmer & $65.77 b$ & $114.22 \mathrm{c}$ & $87.82 \mathrm{a}$ & $10.54 b$ & $3.22 \mathrm{abc}$ & $46.22 \mathrm{a}$ & $6.46 \mathrm{ab}$ & $36.38 \mathrm{ab}$ & $3.13 \mathrm{c}$ \\
\hline Mandoyo & $64.11 \mathrm{c}$ & $114.67 \mathrm{bc}$ & $73.09 \mathrm{c}$ & $9.06 \mathrm{c}$ & $3.58 \mathrm{a}$ & $42.96 \mathrm{ab}$ & $7.45 \mathrm{a}$ & $29.78 \mathrm{e}$ & $3.48 b$ \\
\hline Dure & $59.55 d$ & $108.56 \mathrm{~d}$ & $78.67 \mathrm{bc}$ & $9.39 \mathrm{c}$ & $2.78 \mathrm{c}$ & $45.67 \mathrm{a}$ & $5.81 \mathrm{ab}$ & $31.55 \mathrm{~d}$ & $3.21 \mathrm{c}$ \\
\hline Mean & 65.26 & 115.44 & 81.05 & 10.07 & 3.20 & 43.80 & 6.38 & 34.15 & 3284.43 \\
\hline $\mathrm{cV}$ & 1.67 & 1.96 & 8.36 & 7.65 & 17.32 & 18.04 & 20.60 & 5.17 & 14.74 \\
\hline
\end{tabular}

$\mathrm{FD}=$ days to heading, $\mathrm{DM}=$ days to physiological maturity, $\mathrm{PH}=$ plant height, $\mathrm{SL}=$ spike length, $\mathrm{TN}=$ number of productive tillers, SPS= number of spikelet's per spike, $\mathrm{BM}=$ biomass

\section{Grain yield}

The results of the combined mean of grain yield and yield related parameters over the three consecutive cropping seasons (Table 2). The highest grain yield was obtained from Sanata 4.34, 2.50 and 5.27 tones/ha in 2017, 2018 and 2019 cropping season respectively 
(Table 3). The lowest grain yield was obtained from madawalabu 1.42 tones/ha in 2018 cropping season (Table 3). The result was conspired with the following authors finding Muez et al., (2015); Dargo and Shiferaw, (2017); Chimdesa et al., (2017); Wardofa et al., (2019).

\section{0 kernel weigh}

The thousand grain weights of all the tested bread wheat varieties were significantly differed on which the highest thousand grain weight was recorded in Mada walabu (37.85g) and and Sofumar (36.38g). In other cases, the lowest thousand grain weight was recorded for the variety Mandoyo (29.78g). in the same way, Baye et al., (2018) and Wardofa et al., (2019); Semahegn et al., (2020) reported similar result different bread wheat genotypes across different environments.

\section{Number of spikelet's per spike}

The highest spike length and Seed per Spike for Sanate is an indication of its genetic advantage over the other tested varieties. The highest combined grain yield was recorded for the variety Sanate $(4037.45 \mathrm{~kg} / \mathrm{ha})$ with higher number of seed per spike (51.22) while comparing with the other varieties. This result is concise with the finding of Baye et al., (2018); Alemu et al., (2019); Wardofa et al., (2019)

\section{CONCLUSIONS AND RECOMMENDATION}

The result of the three Environment $\mathrm{s}$ analysis showed that, among the tested bread wheat varieties Sanate was identified as the well performed bread wheat variety over three consecutive Environment s followed by Mandoyo. Hence, cultivation of these bread wheat varieties was recommended in Bule hora district and in other similar wheat growing areas of Southern Oromia.

\section{ACKNOWLEDGMENT}

We sincerely acknowledge the Yabello Pastoral and Dryland Agricultural research center for logistic and budget facilitation and we acknowledge the cereal research case team members for filed management and data collection. Final we want to acknowledge Oromia agricultural research Institute and crop research directorate for funding the project

\section{REFERENCES}

- Abay, F., Bjørnstad, A., \& Smale, M. (2009). Measuring on farm diversity and determinants of barley diversity in Tigray, northern Ethiopia.Momona Ethiopian Journal of Science, 1(2).

- Tefera, A., \& Tefera, T. (2012). Grain and feed annual report. Grain report number: ET1201, Addis Ababa, Ethiopia. aestivum.). Research in Plant Biology, 3(1), 33-36.

- Adhiena, M. (2015). Genetic variability and association among seed yield and yield related traits in bread wheat (Triticum aestivum L.) Genotypes at Ofla District, Northern Ethiopia. M.Sc. Thesis, Haramaya University, Haramaya, Ethiopia.
- $\quad$ Baye, A., Berihun, B., Bantayehu, M., \& Derebe, B. (2020). Genotypic and phenotypic correlation and path coefficient analysis for yield and yield-related traits in advanced bread wheat (Triticum aestivum L.) lines. Cogent Food \& Agriculture, 6(1), 1752603.

- Chimdesa, O., Mohammed, W., \& Eticha, F. (2017). Analysis of genetic variability among bread wheat (Triticum aestivum 1.) genotypes for growth, yield and yield components in Bore district, Oromia regional state. Agriculture, Forestry and Fisheries, 6(6), 188-199.

- Demelash, A., Desalegn, T., \& Alemayehu, G. (2013). Participatory Varietal Selection of Bread Wheat (Triticum aestivum L.) Genotypes at Marwold Kebele, Womberma Woreda, West Gojam, Ethiopia. International Journal of Agronomy and Plant Production, 4, pp.3543-3550.

- Ferede, M. (2016). Stability analysis in bread wheat (Triticum aestivum L.) genotypes in north-western Ethiopia. East African Journal of Sciences, 10(1), 15-22.

- $\quad$ Gebreselassie, S., Haile, M., \& Kalkuhl, M. (2017). The wheat sector in Ethiopia: Current status and key challenges for future value chain development.

- Gebru, H., \& Abay, F. (2013). Evaluation of bread wheat genotypes for their adaptability in wheat growing areas of Tigray Region, Northern Ethiopia. Journal of Biodiversity \& Endangered Species, 1.

- Gedifew, S. (2020). Genetic diversity and association of traits in sesame (sesamum indicum l.) genotypes at northwestern Ethiopia (Doctoral dissertation, Bahir Dar University).

- Kebede, D., Dagnachew, L., Megersa, D., Chemeda, B., Girma, M., Geleta, G., \& Gudeta, B. (2019). Genotype by environment interaction and grain yield stability of Ethiopian black seeded finger millet genotypes. African Crop Science Journal, 27(2), 281-294.

- Mason, N. M., Jayne, T. S., \& Shiferaw, B. A. (2012). Wheat consumption in Sub-Saharan Africa: trends, drivers, and policy implications (No. 1096-2016-88381).

- Mehari, M., Tesfay, M., Yirga, H., Mesele, A., Abebe, T., Workineh, A., \& Amare, B. (2015). GGE biplot analysis of genotype-by-environment interaction and grain yield stability of bread wheat genotypes in South Tigray, Ethiopia. Communications in Biometry and Crop Science, 10(1), 17-26.

- Minot, N., Warner, J., Lemma, S., Kasa, L., Gashaw, A., \& Rashid, S. (2019). The wheat supply chain in Ethiopia: Patterns, trends, and policy options. Gates Open Res, 3(174), 174.

- Ferede, M. (2016). Stability analysis in bread wheat (Triticum aestivum L.) genotypes in north-western Ethiopia. East African Journal of Sciences, 10(1), 15-22. 
- Mehari, M., Tesfay, M., Yirga, H., Mesele, A., Abebe, T., Workineh, A., \& Amare, B. (2015). GGE biplot analysis of genotype-by-environment interaction and grain yield stability of bread wheat genotypes in South Tigray, Ethiopia. Communications in Biometry and Crop Science, 10(1), 17-26.

- Mwadzingeni, L., Shimelis, H., Tesfay, S., \& Tsilo, T. J. (2016). Screening of bread wheat genotypes for drought tolerance using phenotypic and proline analyses. Frontiers in plant science, 7, 1276.

- $\quad$ Rashid, S., Getnet, K., \& Lemma, S. (2019). Maize value chain potential in Ethiopia: Constraints and opportunities for enhancing the system. Gates Open Res, 3(354), 354.

- Semahegn, Y., Shimelis, H., Laing, M., \& Mathew, I. (2020). Evaluation of bread wheat (Triticum aestivum L.) genotypes for yield and related traits under drought stress conditions. Acta Agriculturae Scandinavica, Section B-Soil \& Plant Science, 70(6), 474-484.

- Shibeshi, S. (2019). Performance evaluation of released bread wheat varieties at mid altitude areas of Southern Ethiopia. Ukrainian Journal of Ecology, 9(4).
- Tadesse, W., Bishaw, Z., \& Assefa, S. (2019). Wheat production and breeding in Sub-Saharan Africa: challenges and opportunities in the face of climate change. International Journal of Climate Change Strategies and Management.

- Tarekegne, A., Tanner, D. G., \& Gebeyehu, G. (1995). Improvement in yield of bread wheat cultivars released in Ethiopia from 1949 to 1987. African Crop Science Journal, 3(1).

- Tulu, L., \& Wondimu, A. (2019). Adaptability and yield stability of bread wheat (Triticum aestivum) varieties studied using GGE-biplot analysis in the highland environments of South-western Ethiopia. African Journal of Plant Science, 13(6), 153-162.

- Wardofa, G. A., Mohammed, H., Asnake, D., \& Alemu, T. (2019). Genotype x environment interaction and yield stability of bread wheat genotypes in Central Ethiopia. Journal of Plant Breeding and Genetics, 7(2), 87-94.

- Zerga, K., Mekbib, F., \& Dessalegn, T. (2017). The Mean Performance of Different Bread Wheat (Triticum Aestivum. L) Genotypes in Gurage Zone, Ethiopia. Landscape Architecture and Regional Planning, 2(1), 29-35. 